\title{
Hepatitis B among Indochinese refugees in Great Britain
}

\author{
R. G. CHADWICK \\ M.R.C.P.
}

I. DAVIDSON
Ph.D.

\author{
A. J. HALL \\ M.R.C.P. \\ F. G. BULL \\ D.Phil.
}

R. WRIGHT

D.Phil., F.R.C.P.

Professorial Medical Unit, Southampton General Hospital, Southampton

\begin{abstract}
Summary
Six hundred and thirty-two blood samples from 879 consecutive admissions to one resettlement camp for Indochinese refugees in Great Britain were screened for markers of hepatitis B (HB) virus infection. The overall prevalence of $\mathrm{HB}$ surface antigen (HBsAg) was $15 \%$, being $16 \%$ in those aged 40 years or less, and falling to $8 \%$ in those older than $40(P<0.05)$. No significant difference in prevalence was found between males and females. HBe antigen was detected in 56\% of those with $\mathrm{HBsAg}$ and was demonstrable in $55-76 \%$ of those under 30 years of age. HBe antibody was found in $21 \%$ of $\mathrm{HBsAg}$-positive refugees. In those under 40 years old, $\mathrm{HB}$ core $(\mathrm{HBC})$ antibody was commoner in males $(P<0-01)$. HBc antibody prevalence increased significantly with age in females $(P<0-01)$ but not in males. There was no definite evidence that vertical transmission of hepatitis $B$ was present in the group studied.
\end{abstract}

\section{Introduction}

The high prevalence of hepatitis B (HB) carriage and its related diseases in South East Asia is well known (Stevens et al., 1975). With the end of American involvement in Vietnam some years ago and the subsequent changes in political structure, many people fled from the country as refugees. The route of escape that has received most attention is via the southwest coast of Vietnam to the South China Sea in small, often unseaworthy boats. The survivors of this ordeal have become known as the 'boat people', and a number of Western nations have agreed to resettle a quota of them. Great Britain is one such nation, and expects to resettle between 10,000 and 14,000 refugees. In this country their rehabilitation is administered by three charitable associations, the British Campaign for Aid to Refugees, Save the Children Fund and the Ockenden Venture, which oversee more than 30 camps scattered throughout the country. The first camp opened in August 1979 at Sopley, near Christchurch in Dorset, and the results have been accumulated from admissions to this camp over a period of 8 months.

To date, there have been few major publications surveying the prevalence of infectious diseases in these people. Intestinal infestation with worms, Giardia lamblia and amoebae have been shown in up? to $80 \%$ of populations studied. Malaria, notably due to chloroquine-resistant Plasmodium falciparum, is common (Center for Disease Control, 1979), and the high prevalence of glucose 6-phosphate dehydrogenase deficiency among refugees presents an added problem in treating this disease (Wyler, 1975).

Syphilis is more common than in Western nations (State Department of Health, 1975), and shigellosis and salmonellosis have been found among groups of sick children (Hodson and Springthorpe, 1976). Several cases of leprosy have been reported (Tan and Tan, 1980), but undoubtedly the high prevalences of tuberculosis and hepatitis $B$ are likely to be of greatest significance to public health.

\section{Subjects and methods}

A survey was undertaken to determine the prevalence of hepatitis B virus markers in a group of Indochinese refugees. During the survey period, 879 people were admitted to Sopley camp. Each received a full medical examination on arrival, and during the following 7 days each refugee was asked to give a blood sample: 632 agreed.

HB surface antigen (HBsAg) was measured by a modification by Barbara et al. (1979) of the Hepatest 
passive haemagglutination test (Wellcome Laboratories). HB core ( $\mathrm{HBc}$ ) antibody was estimated by solid-phase competitive radioimmunoassay (Corab, Abbott Laboratories). HBe status was determined by solid-phase radioimmunoassay, using the method of Aldershvile, Frösner and Nielsen (1980). Statistical significance was tested according to Van Tassel (1981).

\section{Results}

The overall prevalence of $\mathrm{HBsAg}$-positivity was $15 \%$; it was $16 \%$ in those aged 40 years or less, but fell to $8 \%$ above the age of $40(P<0.05)$ (Fig. 1). No significant difference could be found by comparing male with female $\mathrm{HBsAg}$ positivity, either as a whole cr subgrouped into those above and below 40 years of age. In contrast, the prevalence of $\mathrm{HBc}$ antibody was $45 \%$ at 10 years and rose steadily to reach $90 \%$ at 40 years (Fig. 2). This increase was significant in females when comparing those aged 40 or less with those older than 40 years $(P<0.01)$. Significance was not achieved in the males treated similarly. However, in those aged 40 or less, $\mathrm{HBc}$ antibody was commoner among males than females $(P<0 \cdot 01)$. HBe status could be assigned in $77 \%$ of the $\mathrm{HBsAg}$ positive subjects, $\mathrm{HBe}$ antigen was found in $56 \%$ and $\mathrm{HBe}$ antibody in $21 \%$. Age distribution of $\mathrm{HBe}$ antigen and antibody (Fig. 3) confirmed the high prevalence of $\mathrm{HBe}$ antigen among younger refugees, with $\mathrm{HBe}$ antigen demonstrable in $55-76 \%$ of those under 30 years of age.

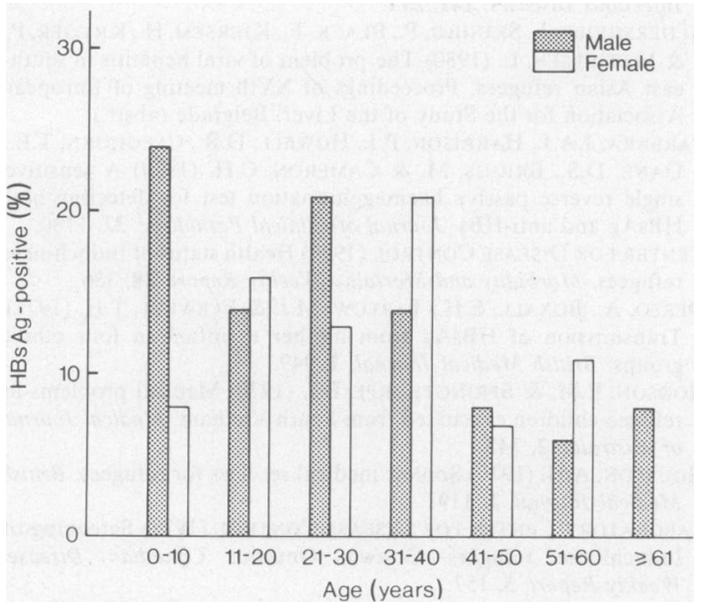

FIG. 1. Prevalence of HBsAg by age and by sex in 632 Indochinese refugees.

\section{Children of HBsAg-positive parents}

Family clustering of $\mathrm{HBsAg}$ positive children with

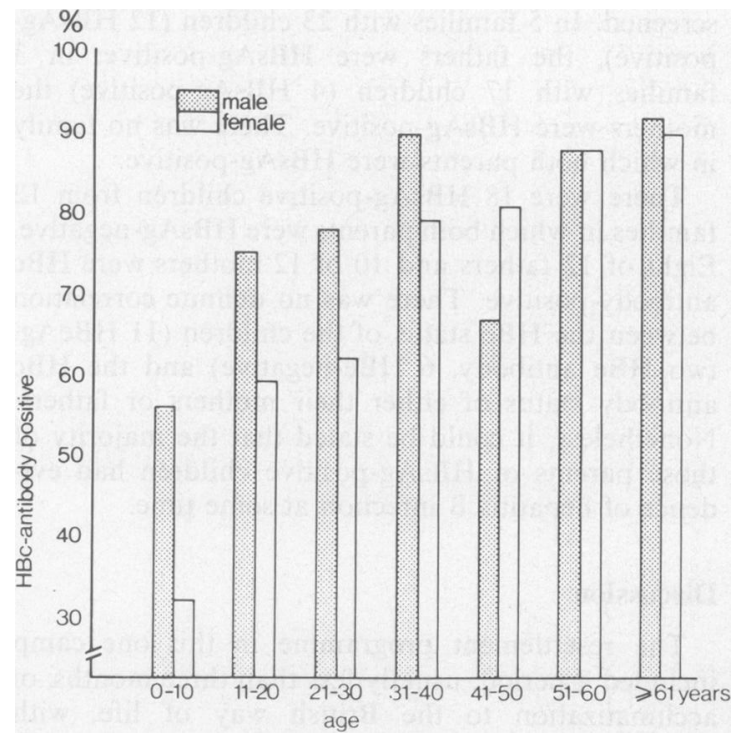

FIG. 2. Prevalence of $\mathrm{HBc}$ antibody by age and by sex in 620 Indochinese refugees.

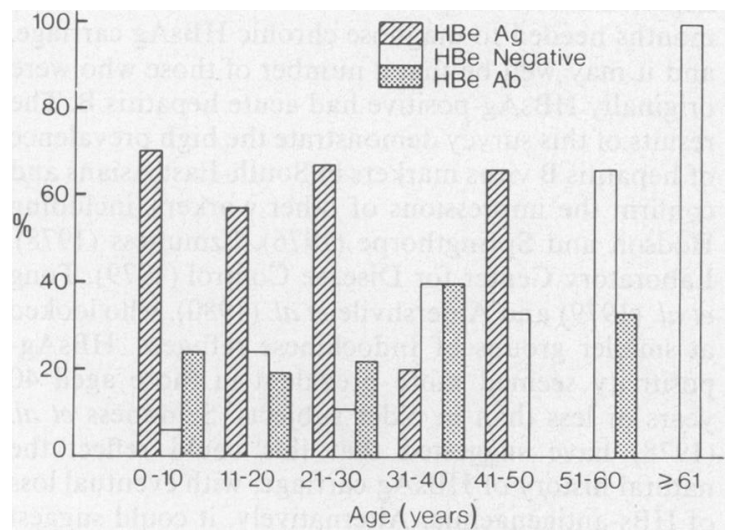

FiG. 3. Prevalence of $\mathrm{HBe}$ antigen, $\mathrm{HBe}$ antibody and $\mathrm{HBe}$ negative tests by age in $82 \mathrm{HBsAg}$-positive Indochinese refugees.

HBsAg positive parents was investigated. It was possible to find only 20 families in which parents were available with their children for screening and subsequently proved to be $\mathrm{HBsAg}$-positive. Of 12 HBsAg-positive mothers with one or more children, only 3 had $\mathrm{HBsAg}$-positive children. Of $16 \mathrm{HBsAg}$ positive fathers, only 5 had $\mathrm{HBsAg}$-positive children. $\mathrm{HBe}$ antigen was found in one of these fathers, but in none of the mothers.

\section{Parents of HBsAg-positive children}

Twenty families with a total of 107 children, and at least one $\mathrm{HBsAg}$-positive child in each family, were 
screened. In 5 families with 23 children $(12 \mathrm{HBsAg}-$ positive), the fathers were $\mathrm{HBsAg}$-positive; in 3 families with 17 children (4 HBsAg-positive) the mothers were $\mathrm{HBsAg}$-positive. There was no family in which both parents were $\mathrm{HBsAg}$-positive.

There were $18 \mathrm{HBsAg}$-positive children from 12 families in which both parents were $\mathrm{HBsAg-negative.}$ Eight of 12 fathers and 10 of 12 mothers were $\mathrm{HBc}$ antibody-positive. There was no definite correlation between the $\mathrm{HBe}$ status of the children $(11 \mathrm{HBeAg}$, two $\mathrm{HBe}$ antibody, $6 \mathrm{HBe}$-negative) and the $\mathrm{HBC}$ antibody status of either their mothers or fathers. Nonetheless, it could be stated that the majority of those parents of $\mathrm{HBsAg}$-positive children had evidence of hepatitis B infection at some time.

\section{Discussion}

The resettlement programme in this one camp included a period, usually less than three months, of acclimatization to the British way of life, with English language teaching and health care. After this time the refugee families were dispersed all over Britain. It was therefore impracticable to repeat hepatitis B screening after the minimum three to six months needed to diagnose chronic HBsAg carriage, and it may well be that a number of those who were originally HBsAg-positive had acute hepatitis B. The results of this survey demonstrate the high prevalence of hepatitis B virus markers in South-East Asians and confirm the impressions of other workers, including Hodson and Springthorpe (1976), Szmuness (1978), Laboratory Center for Disease Control (1979), Tong et al. (1979) and Aldershvile et al. (1980), who looked at smaller groups of Indochinese refugees. $\mathrm{HBsAg-}$ positivity seemed more prevalent in those aged 40 years or less than in older subjects. Szmuness et al. (1978) have suggested that this could reflect the natural history of $\mathrm{HBsAg}$ carriage, with eventual loss of HBs-antigenaemia. Alternatively, it could suggest increased early mortality of $\mathrm{HBsAg}$ carriers from chronic liver disease and hepatoma (Szmuness, 1978; Tong et al., 1979). The high prevalence of $\mathrm{HBe}$ antigen among South-East Asian hepatitis carriers and the increasing prevalences of $\mathrm{HBc}$ and $\mathrm{HBe}$ antibody with age have been reported by Richer $e$ al. (1977), Szmuness et al. (1978) and Derso et al. (1978) in similar groups in which hepatitis is endemic; the falling prevalence of $\mathrm{HBe}$ antigen with increasing age has also been noted previously by Szmuness $e t$ al. (1978).

The results were insufficient to show any apparent clustering of $\mathrm{HBsAg}$-positive children around HBsAg-positive parents, or definite evidence of vertical transmission of hepatitis B from HBsAgpositive parents to children. This is in contrast to the results of Aldershvile et al. (1980) surveying a similar group of refugees in Denmark, which showed that child $\mathrm{HBsAg}$ carriers clustered around $\mathrm{HBsAg} / \mathrm{HBe}$ antigen positive mothers only. The reasons for this difference probably lie in the small numbers of 'complete families' available for screening. Most families had lost either parents or children, leaving small numbers available for this part of the study. Furthermore, there was a distinct impression that some of the 'families' had been assembled from unrelated persons (Houston, 1979). The high prevalence of $\mathrm{HBc}$ antibody in both parents and children in these families, together with single $\mathrm{HBsAg}$-positive children among many HBsAg-negative siblings, suggest that the infection was probably spread horizontally.

Alternatively, the vertical passage of infection during an attack of acute hepatitis $B$ in the third trimester of pregnancy, with subsequent clearing of maternal $\mathrm{HBs}$ antigenaemia, may explain these findings. If this were so, and assuming that only one HBsAg-subtype was involved, only one child in each family could be infected. The most likely explanation would seem to be that both horizontal and vertical spread of infection occur in those refugees studied, but the relatively small group studied and the large number of fragmented families made it difficult to demonstrate this.

\section{References}

AldershVile, J., Frósner, G.G. \& Nielsen, J.O. (1980) Hepatitis $B$ e antigen and antibody measured by radioimmunoassay in acute hepatitis B surface antigen-positive hepatitis. Journal of Infectious Diseases, 141, 293.

AldershVile, J., Skinhøj, P., Black, F., KJersem, H., Kryger, P. \& MATHIESEN, L. (1980) The problem of viral hepatitis in southeast Asian refugees. Proceedings of XVth meeting of European Association for the Study of the Liver, Belgrade (abstr.)

Barbara, J.A.J., Harrison, P.J., Howell, D.R., Cleghorn, T.E., DANe, D.S., BRiggs, M. \& CAMERon, C.H. (1979) A sensitive single reverse passive haemagglutination test for detecting both HBsAg and anti-HBs. Journal of Clinical Pathology, 32, 1180.

CENTER FOR DISEASE CONTROL (1979) Health status of Indochinese refugees. Morbidity and Mortality Weekly Report, 28, 386.

Derso, A., BoXall, E.H., TARLOW, M.J. \& FLEWETT, T.H. (1978) Transmission of $\mathrm{HBsAg}$ from mother to infant in four ethnic groups. British Medical Journal, 1, 949.

HODSON, E.M. \& SPRINGTHORPE, B.J. (1976) Medical problems in refugee children evacuated from South Vietnam. Medical Journal of Australia, 2, 747.

HousTON, A.H. (1979) Sopley: medical services for refugees. British Medical Journal, 2, 1191.

LABORATORY CENTER FOR DISEASE CONTROL (1979) Screening of Indochinese refugees-Ottawa, Ontario. Canadian Diseases Weekly Report, 5, 157.

Richer, G., Phaneuf, D., Boisvert, F., Guerin, R. \& Viallet, A. (1977) Differences in the distribution of e antigen among different ethnic groups in a population of blood donors. Canadian Medical Association Journal, 116, 757.

STATE DEPARTMENT OF HEALTh (1975) Health problems of Vietnamese refugee children. Journal of the Iowa Medical Society, 65, 508.

SteVens, C.E., Beasley, R.P., Tsui, J. \& LEE, W.-C. (1975) Vertical 
transmission of hepatitis B antigen in Taiwan. New England Journal of Medicine, 292, 771.

SZMUNESS, W. (1978) Hepatocellular carcinoma and the hepatitis B virus: evidence for a causal association. Progress in Medical Virology, $24,47$.

Szmuness, W., Harley, E.J., IKRam, H. \& Stevens, C.E. (1978) Sociodemographic aspects of the epidemiology of hepatitis B. In: Viral Hepatitis (Ed by Vyas, G.N., Cohen, S.N. \& Schmid, R.) Proceedings of the 2nd Symposium on Viral Hepatitis, University of California. Franklin Institute Press.

TAN, J.K. \& TAN. K.K. (1980) Health problems of Vietnamese refugees. Canada Family Physician, p. 401-408, attributed to Morbidity and Mortality Weekly Report, 24 (1976), 455.
Tong, M.J., Weimer, J.M., Aschcaval, M.W., Redeker, A.G., CoMPARINI, S. \& VYAS, G.N. (1979) A comparative study of hepatitis B viral markers in the family members of Asian and nonAsian patients with hepatitis B surface antigen-positive hepatocellular carcinoma and with chronic hepatitis B infection. Journal of Infectious Diseases, 140, 506.

VAN TASSEL, D. (1981) Test of difference of two proportions. In: Basic-pack Statistic Programs for Small Computers, p. 201. Prentice Hall, Hemel Hempstead.

WYLER, D.J. (1975) South-east Asian refugees and malaria. New England Journal of Medicine, 293, 203. 